\title{
Lis Moller
}

\section{Grænser}

\section{Om grænsen som figur hos William Wordsworth og Emily Dickinson}

\section{Den indre og den yderste grense}

I begyndelsen af anden bog af The Prelude ${ }^{1}$ afbryder det fortællende, erindrende jeg pludselig sin retrospektive fortællestrøm for i en metanarrativ kommentar at give udtryk for bevidstheden om den kløft, der skiller ham selv fra det barn, han engang var.

so wide appears

The vacancy between me and those days,

Which yet have such self-presence in my mind

That, sometimes, when I think of it, I seem

Two consciousnesses, conscious of myself

And of some other Being.

(The Prelude, 2:28-33)

Det er billedet af et spaltet eller måske mere præcist et dobbelt selv, der fremmanes. 'Jeg' er »myself«, men samtidig en anden: et tidligere selv der på een gang opleves som nærværende, som fortsat eksiterende, og som fraværende, som fremmed for det erindrende jeg. Før og nu, fortidig og nuværende bevidsthed er adskilt af et tomrum, af et svælg der både er tidsligt og rumligt: en afstand i tid oplevet som en indre, sjalelig barriere.

Inderliggørelsen af fortiden postulerer en tidløshed, der (momentant) redder jeg'et fra bevidstheden om livet som lineær sekvens af begivenheder, bevidstheden om tidens ubønhørlige gang. At fremstille forholdet mellem for og nu som en intrapsykisk synkron struktur er at insistere på fortidens permanens, og dens fortsatte aktualitet. Intet er gået tabt; alt er opbevaret. »At forbinde den fjerneste fortid med 
vores inderste dybde er en måde at afvise tab og adskillelse på« skriver Jean Starobinski. ${ }^{2} \mathrm{Og}$ at benægte tabet af fortiden synes at være en poetisk nødvendighed for Wordsworth, der søger at basere sin egen digteriske eksistens på den vedvarende fornyelse, der udgår fra barndommens "Visitings of imaginative power" (1 I:253). Tematiseringen af fortiden som inderlighed eller sjælelig dybde fremtræder som selve forudsætningen for Wordsworths autobiografiske projekt, nemlig at afdække »the hiding-places of my power" (1l:336) og fremskrive forestillingskraftens fundament.

Men i samme bevægelse som jeg'et bekræfter fortidens tidløshed og hermed muligheden for en intro-retrospektiv tilbagevenden, konfronteres det jeg, der vandrer $\mathrm{i}$ erindringens landskab, med bevidstheden om at være decentreret, adskilt fra sin egen (poetiske) væsenskerne. Hvis den barndom, der associeres med styrke, opleves som inderliggjort og dermed nærværende, forekommer den samtidig at være uden for jeg'ets rækkevidde.

The days gone by

Come back upon me from the dawn almost

Of life: The hiding-places of my power

Seem open; I approach, and then they close

(11:334-37)

»Tabet« genintroduceres $\mathrm{i}$ form af en indre tærskel. Vi kan således læse »Boy of Winander «-passagen ${ }^{3}$ som en emblematisk fremstilling af dette spaltede selv. I billedet af den forunderlige dreng, som »died / In childhood, ere he was full ten years old « (5:414-15), og det voksne jeg, der står "Mute-looking at the Grave in which he lies" (5:422), personificeres digterens to bevidstheder, det erindrede og det erindrende jeg, det fortidige og det nuværende selv. Som en sørgende efterladt står det erindrende jeg ved sit tidligere selvs gravsted.

Følelsen af at være "two consciousnesses«, dvs. erkendelsen af at stå overfor en »vacancy«, der gør det erindrede selv til en anden, et fraværende nærvær eller nærværende fravær, gennemtrænger hele The Prelude. I forskellige variationer gennemspilles den figur, der strukturerer fremstillingen af selvet og tidsforholdet i Wordsworths autobiografiske digt: Jeg'et stående ved eller på en grænse, en barriere eller en 'overflade', der deler en 'nedre' region fra en 'øvre' eller en 'indre' fra en 'ydre'. Det er denne figur, dens kompleksitet og flertydighed, der er emnet for den følgende læsning af The Prelude, og som videre vil danne bindeled mellem The Prelude og Emily Dickinson's lyriske digtning. ${ }^{4}$ 
Forbindelsen mellem Emily Dickinson og den engelske romantik (herunder Wordsworth) er et felt, der først nu er i færd med at blive kortlagt. »Der mangler endnu en gennemgribende fortolkning af hendes digtning i lyset af den romantiske tradition «, påpeger Joanne Feit Diehl. "Det er kun gennem en sådan fortolkning, vil jeg hævde, at vi kan begynde at fatte det Dickinsonske storværks eksperimentelle dristighed og revolutionære karakter. $\ll^{5}$ Nærværende fremstilling skal begrænse sig til et enkelt aspekt af en sådan fortolkning, nemlig grænsen, tærsklen, barrieren mellem jeg'et og den anden / det andet, der er et centralt anliggende - måske det centrale - for Wordsworth såvel som for Dickinson.

Som bekendt er tærsklen - typisk selve graven som grænse mellem liv og død - et genkommende billede i Dickinson's digtning. Og som i The Prelude er denne figur uløseligt forbundet med erfaringen om og fremstillingen af selvet: Den poetiske introspektion, udforskningen af sindets "'Undiscovered continent' " (P. 832), af forholdet mellem sprog, subjekt og tidslighed er fællesanliggender for Wordsworth og Dickinson. Men det er samtidig på denne baggrund at forskellene og modsætningerne - Dickinson's afbøjning fra romantikken - træder frem. Mest åbenlys er modsætningen mellem den Wordsworthske retrospektion og den Dickinsonske anticipation. Hos Wordsworth er grænsen som figur relateret til erindringsfunktionen, til tilbageblikket; det er i udforskningen af grænsen mellem fortid og nutid, mellem tidligere og nuværende jeg'er, at Wordsworth søger at fundere sit poetiske selv. Hos Dickinson spores ingen nostalgi efter en tidligere væren: den barriere, hendes digte udforsker, er ikke den, der skiller det talende jeg fra det begravede barn eller nu'et fra fortidens »visionary gleam «, men først og fremmest den grænse, der ligger forud tærsklen mellem det finite og det infinite - hinsides hvilken jeg'et søger »Its own Identity" (P. 822). Den tidløshed, hun ønsker at fremskrive, er ikke den inderliggjorte fortids formodede permanens, men en tidløshed der har karakter af intethed eller evighed. »Hvad hun stræber efter «, siger Diehl, "er ikke ... så meget en heling af spaltningen mellem Mig og Ikke Mig som en direkte, umiddelbar konfrontation med døden, hvorfra hun håber at hente sin privilegerede vision." (op.cit. p. 11)

Men forholdet mellem den Wordsworthske og den Dickinsonske grænseerfaring kan ikke reduceres til en simpel symmetrisk modsætning mellem analepsis og prolepsis $;{ }^{6}$ snarere har vi at gøre med to radikalt forskellige poetiske udtryk. I forsøget på at tage sit fortidige selv i besiddelse står det Wordsworthske 'jeg' ved en grænse - en 'overflade' - der synes snart uigennemtrængelig og snart transparent, 
snart genspejlende, snart åben og snart lukket, men som det retrospektive blik ikke kan - og ikke må - annullere. Hos Dickinson er den poetiske diskurs såvel en afmærkning af den yderste grænse som en radikal overskridelse. I visse digte bevæger jeg'et sig frem mod selve tærsklen for derefter at tvinges tilbage; det andet anes, men forbliver et terra incognita.

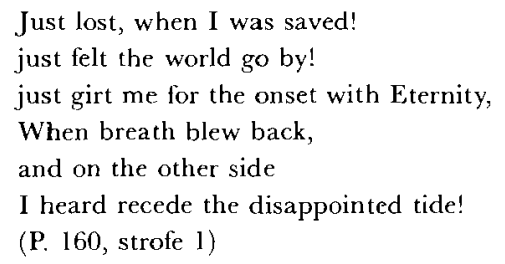

I andre (som vi skal se) fuldføres bevægelsen, og den poetiske stemme taler fra et sted hinsides tærsklen. Eller måske snarere: stemmen bevæger sig frem og tilbage over grænser, der selv gøres til genstand for redifinitioner og forskydninger. Den Dickinsonske 'afbøjning', som Diehl taler om, beror i høj grad på denne 'bevægelighed', som i sig selv er en (poetisk) grænseoverskridelse, der ikke blot kan bestemmes tematisk: det er samtidig, som jeg afslutningsvis skal antyde, selve grænsen mellem det figurative og det bogstavelige, der står på spil.

"Incumbent o'er the surface of past time ..."

I felt a Cleaving in my Mind -

As if my Brain had split -

I tried to match it - Seam by Seam -

But could not make them fit.

The thought behind, I strove to join

Unto the thought before -

But Sequence ravelled out of Sound

Like Balls - upon a Floor.

(P. 937)

Således beskriver Dickinson i et digt fra 1864 en til galskab grænsende kløvning af sindet. Spaltningen inficerer sproget og får ordene til at falde fra hinanden. Eller rettere, fragmenteringen af sproget, opløsningen af sproglig logik og sammenhæng, er selve den sjælelige spalt- 
ning; det sønderbrudte sprog og det revnede sind er eet og det samme. Samme markering af sprogets rolle i forbindelse med oplevelsen af indre spaltning finder vi i The Prelude - blot med den væsentlige forskel, at her er det ikke sætningerne, der går itu, men selve sproget der, som indbegrebet af forskel og afstand, fremstår som den spaltende instans. Subjektets indtræden i sproget indstifter en adskillelse, en frcmmedhed, som sproget både afslører og søger at dække over. Selve det erindringsprojekt, som The Prelude er, er mærket af et uopløseligt paradoks: forsøget på at give sprogligt udtryk for det uudsigelige, forsøget på i ord at fremstille det, der »lies far hidden from the reach of words « $(3: 185)$. Hos Wordsworth forekommer ordene at være en andenrangs erstatning for "mute dialogues« (2:283), som selve sprogligheden umuliggør. Sproget fremstår, skriver Frances Ferguson, som »et forsøg på at kommunikere på tværs af forskelle, hvor forskelle tidligere ikke syntes at eksistere. $\aleph^{7}$

"Boy of Winander «-passagen kan læses som en idealisering af den ordløse dialog og af det barn, der måtte dø for at manden kunne fødes, eller som drømmen om et sprog hinsides ordene.

There was a Boy, ye know him well, ye Cliffs

And Islands of Winander! many a time

An evening, when the stars had just begun

To move along the edges of the hills,

Rising or setting, would he stand alone Beneath the trecs, or by the glimmering Lake, And there, with fingers interwoven, both hands

press'd closely, palm to palm, and to his mouth

Uplifted, he, as through an instrument,

blew mimic hootings to the silent owls

That they might answer him. - And they would shout

Across the watry Vale, and shout again,

Responsive to his call, with quivering peals,

And long halloos, and screams, and echoes loud

Redoubled and redoubled; concourse wild

Of mirth and jocund din! And when it chanced

That pauses of deep silence mock'd his skill,

Then sometimes, in that silence, while he hung

Listening, a gentle shock of mild surprize

Has carried far into his heart the voice

Of mountain torrents; or the visible scene

Would enter unawares into his mind

With all its solemn imagery, its rocks,

Its woods, and that uncertain Heaven, receiv'd

Into the bosom of the steady Lake. 
This Boy was taken from his Mates, and died In childhood, ere he was full ten years old.

- Fair are the woods, and beauteous is the spot,

The Vale where he was born; the Churchyard hangs

Upon a Slope above the Village School,

And there, along that bank, when I have pass'd

At evening, I believe that oftentimes

A full half-hour together I have stood

Mute - looking at the Grave in which he lies.

$(5: 389-422)^{8}$

Det er som om det voksne jeg med sit erindrende blik søger at slå bro over kløften mellem ham selv og det barn, han engang var, drengen der talte uglernes sprog og blev eet med selve landskabet. Men svælget mellem de to er uoverstigeligt som grænsen mellem den døde og den efterladte. Hvor drengens mimetiske fugleskrig affødte en dialog på tværs af »the watry Vale« - en dialog der voksede i intensitet for til slut at forvandles til et ordløst, tyst fællesskab - så formår det voksne jegs stumme blik ikke at overvinde afstanden til sit tidligere selv. Graven forbliver intakt, og dette faktum kaster, paradoksalt nok, et skær af 'død' over det 'levende' jeg, der, stående på den selvsamme bred men berøvet barnets ordløse sprog, fremtræder som tomt og livløst.

Afstand og adskillelse kommer til at konnotere levende død. Men ophævelsen af forskel og afstand er ligeledes dødbringende: den ordløse dialogs klimaks er samtidig Winanderdrengens (symbolske) udslettelse. Mens »the visual scene" trænger dybt ind i drengens hjerte, så modtager »the bosom of the steady Lake " $i$ en tilsvarende bevægelse det omkransende landskab. Det er verbet »modtage (»receiv'd «), der er så påfaldende: landskabet genspejles ikke; det opsluges af søen. Som natursceneriet synker ned i sjælen, således 'synker' også drengen - nu selv en del af landskabet - ned i søens dyb. »I ophøjede øjeblikke«, skriver Charles Sherry, »hvor sind og natur smelter sammen til eet prospekt, er der et fravær af mening, en stilhed som sind og natur synker ned i.« ${ }^{9}$ Winander-drengens (symbolske) død er et sådant "fravær af mening «. På den ene side idealiseres symbiosen mellem jeg'et og det andet; på den anden side er denne symbiose, som Ferguson udtrykker det, en allegori på den rædsel, der ville være forbundet med opfyldelsen af den utopiske drøm om et perfekt mimetisk sprog. ${ }^{10}$

I en berømt passage fra The Prelude Bog IV sammenligner det erindrende jeg sig selv med en, der fra en lille båd på »the breast / Of a still water« (4:248-49) bøjer sig frem over vandoverfladen for 
med sit blik at udforske de »beauteous sights« (4:252), der gemmer sig "in the bottom of the deeps « (4:251). Men det tilbageskuende jeg, der »Incumbent o'er the surface of past time« ransager den inderliggjorte fortids dyb, forbliver udspæendt mellem de to positioner, som »Boy of Winander « afmærker: udspændt mellem tanken om 'drukning' og tanken om den mentale 'indtørring', mellem den stilhed der er "absence of meaning « og stumheden hos det jeg, der betragter sit tidligere seivs grav. Billedet af den stille vandoverflade, der på een gang bærer oppe og tillader blikket at passere, får ikke lov at blive stående The Prelude. Som i »Boy of Winander«: Den glitrende søoverflade (der i kraft af »bosom« (5:413) klart associerer til »breast / Of a still water «) forvandles til en absorberende substans. I et kort nu åbnes denne grænse, og drengen trækkes ned i dybet; derefter lukkes den atter. Vandoverfladen stivner til et gravmonument; selve søen bliver metafor for det gravsted, som den metonymisk er forbundet med.

I prosastykket Essays upon Epitaphs sammenligner Wordsworth de mindeskrifter, der pryder en landsbykirkegård, med en rolig havoverflade. Den sammenhæng mellem grav og vand og mellem 'dybet' og 'fortiden', som »Boy of Winander« antyder, bliver her til en eksplicit analogi:

Amid the quiet of a Church-yard thus decorated as it seemed by the hand of memory, and shining, if I may so say, in the light of Love, I have been affected by sensations akin to those which have risen in my mind, while I have been standing by the side of a smooth Sea, on a Summer's day."

Selve kirkegården - »the smooth Sea« - synes at være kvintessensen af kærlig erindring. Men pludselig afbrydes betragterens behagelige, næsten sentimentale, dagdrøm af »a consciousness ... flashing upon me« (ibid. p. 64). I fantasien drages jeg'et ned under den glatte overflade og han fyldes af en radsel, der aldrig kommer åbent til udtryk i The Prelude. Tanken trænger ned sinto the depths of that sea« (ibid. p. 64) - og det er ikke »beauteous sights « men hæslige monstrer, som den møder under denne »surface of past time«.

The image of an unruffled Sea has still remained; but my fancy has penetrated into the depths of that Sea - with accompanying thoughts of Shipwreck, of the destruction of the mariner's hopes, the bones of drowned Men heaped together, monsters of the deep, and all the hideous and confused sights which Clarence saw in his Dream! (ibid. p. 64)

Angstvisionen indeholder indirekte en hentydning til digterens bror, John Wordsworth, der i 1805 omkom ved et forlis (blot eet af de 
mange traumatiske dødsfald i digterens familie, som The Prelude kun strejfer). Men denne bogstavelige drukning bliver figur for en symbolsk tilintetgørelse: den implicitte forestilling om jeg'ets udslettelse idet det trænger ned i fortiden, ned i det dyb der er skjult under overfladen. Kun gennem hvad der forekommer at være en kraftanstrengelse, lykkes det tanken at vende tilbage til denne overflade, til »the smooth surface and ... fair ... outside« (ibid. p. 64). Jeg'et fixerer blikket på de inskriptioner, der før fremstod som behagelige løgne om fortiden, men som nu bliver den redningsplanke, bevidstheden klynger sig til. Mens den uigennemtrangelige grav i »Boy of Winander« er et emblem på den dødlignende eksistens, som er resultatet af det erindrende jegs fremmedgjorthed fra det fortidige selv 'nedenunder', så bliver gravstenene i Essays ... en beskyttende barriere, et skjold mod »the monsters of the deep«. Graven - grænsen, barrieren, tærsklen - bliver et fortrængningens mærke.

Drukning og oversvømmelse er hyppige billeder i The Prelude, ${ }^{12}$ og de bærer vidnesbyrd om den ambivalens, der kendetegner selve erindringsprojektet. Ønsket om at huske er nært forbundet med ønsket om (eller nødvendigheden af) at glemme. Begæret efter et poetisk sprog, der kan slå bro over svælget mellem jeg'ets »two consciousnesses« og tilbageerobre den tabte tid, kalder ikke blot på bevidstheden om, at fortidens meningsfuldhed beror på afstand og forskel, men også på behovet for ved hjælp af grænser og barrierer at beskytte sig mod fortiden.

Men som sagt: angsten for den brutale konfrontation med fortiden modsvares af frygten for aldrig at kunne gennembryde "the surface of past time«. Måske er fortiden - og dermed det selv og den sensibilitet, som Wordsworth baserer sin poetiske identitet på - for altid udenfor rækkevidde. Måske er det erindrende jeg, i sin søgen efter sig selv, dømt til at stoppe op foran en barriere, som han ikke kan gennembryde, eller en kløft, som hans sprog ikke kan slå bro over. Måske er hele det (selv)erkendelsesprojekt, som The Prelude er, fra starten mærket af fiasko. Angstforestillinger som disse vibrerer i baggrunden og kommer åbent til udtryk, f.eks. i beskrivelsen af jeg'ets møde med den blinde tigger i London.

'twas my chance

Abruptly to be smitten with the view

Of a blind Beggar, who, with upright face,

Stood propp'd against a Wall, upon his Chest

Wearing a written paper, to explain

The story of the Man, and who he was.

My mind did at that spectacle turn round 
As with the might of waters, and it seemed

To me that in this Label was a type,

Or emblem, of the utmost that we know,

Both of ourselves and of the universe;

And, on the shape of the unmoving man

His fixed face and sightless eyes, I look'd

As if admonish'd from another world.

$(7: 610-23)$

Jeg'et besværges som fra det hinsides - men visionen er selve erkendelsen af, at grænsen aldrig kan overskrides og at den anden aldrig kan erkendes eller fremskrives. Som en levende død frembærer den blinde, ubevægelige tigger den »Label«, der på een gang er en slags gravinskription, en 'overflade' - der, qua sin placering på tiggerens "Chest«, associerer til den vandoverflade, det "breast«, der skjuler »the bottom of the deep« - og en 'grænse' mellem det ydre og det indre og mellem jeg'et og den anden. (Tilbage)blikket og (selv)erkendelsen stopper ved denne uigennemtrængelige og uigennemsigtige barriere. Som et emblem på erkendelsens begrænsning håner tiggerens "Label « det erindrende jegs forsøg på at tage fortiden og sit andet selv i besiddelse. Det beskrevne papir, der fortæller »the story of the Man, and who he was« bliver et vrængbillede på jeg'ets egen autobiografiske beretning. Som sådan er tiggercns "Label« en ny version af overflade-figuren i The Prelude - for hvad den antyder er, at der måskc ikke er noget at erkende under denne overflade, hverken »beauteous sights« eller »monsters of the deep«.

Spillet mellem 'dybde' og 'overflade' genfinder vi i den analogi for erindringsfunktionen, som jeg tidligere har citeret uddrag af:

\footnotetext{
As one who hangs down-bending from the side

Of a slow-moving Boat, upon a breast

Of a still water, solacing himself

With such discoveries as his eye can make,

Beneath him, in the bottom of the deeps,

Sees many beauteous sights, weeds, fishes, flowers,

Grots, pebbles, roots of trees, and fancies more;

Yet often is perplex'd, and cannot part

The shadow from the substance, rocks and sky,

Mountains and clouds, from that which is indeed

The region, and the things which there abide

In their truc dwelling; now is cross'd by gleam of his own image, by a sunbeam now, and motions that are sent he knows not whence,

Impediments that make his task more sweet;
} 
- Such pleasant office have we long pursued

Incumbent o'er the surface of past time

With like succes;

$(4: 247-64)$

Passagen indledes med hvad der synes at være et (utopisk) idealbillede på den Wordsworthske erindring: balancen mellem sikker afstand og gennemsigtighed. Men "the surface of past time« er ikke blot et vindue ned til en smuk og fascinerende underverden; det er også en genspejlende flade, der destabiliserer relationen mellem 'nedre' og 'øvre', 'indre' og 'ydre', substans og skygge, fortid og nutid, det erindrede og den erindrende. Det er to forskellige billeder på 'fortidsoverfladen', der her bringes sammen: den overflade, der dækker over »the bottom of the deep«, over fortiden / det fortidige selv som (indre) dybde, og den overflade, der er et spejl, hvis dybde er en refleksionseffekt. Jeg'et bøjer sig frem over vandets reflekterende flade, og i selve denne bevægelse etableres endnu en variation af figuren 'det fordoblede selv'. I søens forvirrende sammenblanding af substans og skygge ser han et 'selv': ikke "some other Being«, der stiger op fra fortidens dyb, men det billede af ham selv, der aftegnes på "the surface of past time«. Den tvetydighed, der overalt i The Prelude karakteriserer behandlingen af forholdet mellem jeg'et og 'det andet' (Naturen) - er den "spirit«, som digteren forbinder med naturen, noget i naturen iboende, eller er den en projektion? - udstrækkes, qua spejlmetaforen, til også at omfatte forholdet mellem det erindrende jeg og det fortidige selv: Er dette selv et autentisk selv, der eksisterer uafhængigt af det retrospektive blik, eller konstitueres det netop af selve blikket?

Grænsen mellem fortid og nutid, mellem det erindrende jeg og 'den anden', er grundvilkåret for det Wordsworthske projekt; dens ophævelse kan kun tematiseres som jeg'ets symbolske død. Men hvordan skal denne grænse læses? Digtet bevæger sig frem og tilbage mellem forskellige billeder: den transparente flade; den uigennemtrængelige barriere (der benægter det intro-retrospektive projekts mulighed); spejlet (der sammenbringer kvaliteter som transparens og uigennemtrængelighed, (visuel) 'dybde' og overflade). Det er selve spændingsfeltet mellem disse forskellige grænsefigurer, der er The Preludes domæne. 
"Odd secrets of the line to tell"

\author{
How the Waters closed above Him \\ We shall never know - \\ How He streched His Anguish to us \\ That - is covered too - \\ Spreads the Pond Her Base of Lilies \\ Bold above the Boy \\ Whose unclaimed Hat And Jacket \\ Sum the History - \\ (P. 923)
}

Vi kan læse ovenstående lille digt som Emily Dickinsons kommentar til passagerne om Winanderdrengen og den druknede mand. ${ }^{13}$ Dickinson synes med et enkelt pennestrog at afvise det Wordsworthske erindringsprojekt: Den åkandebedækkede dam har taget drengen til sig og lukket sig over hans hovede - historien ender her; ethvert forsøg på at fravriste søens dens hemmelighed er udelukket. Og dog er det netop gransen, som Dickinsons poesi vil udforske - ikke Wordsworths »surface of past time«, men døden (hvadenten den læses figurativt eller bogstaveligt): døden som på een gang ultimativ grænse og grænsernes ultimative sammenbrud.

Grænsen er, som hos Wordsworth, en kompleks og flertydig figur; det Dickinsonske jeg både viger tilbage for og higer mod konfrontationen med 'det andet', det hinsidige, og denne ambivalens gennemsyrer en række af hendes bedste digte. Billedet af den druknede »Upon the waters borne - / With eyes in death - still begging raised - / And hands - beseeching - thrown! (P. 201) er een version af den Dickinsonske grænseerfaring; jeg'et, der 'fortabes', idet det i yderste sekund franarres døden som absolut erkendelse, er en anden:

Just lost, when I was saved!

Just felt the world go by!

Just girt me for the onset with Eternity,

When breath blew back,

And on the other side

I heard recede the disappointed tide!

Therefore, as One returned, I feel

Odd secrets of the line to tell!

Some Sailor, skirting foreign shores -

Some pale Reporter, from the awful doors

Before the Seal! 


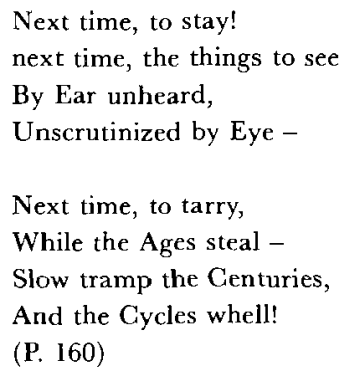

Evighedens opslugende tidevand trækker sig tilbage og efterlader jeg'et, hungrende efter den erfaring, det blev nægtet. Den talende udpeger det punkt, hvor liv og 'evighed' mødes. På selve tærkslen rives jeg'et tilbage til 'verdenen', men vender tilbage som en, der allerede er mærket af »the other side“. Jeg'et vender tilbage som en, der må fortælle modd secrets of the line«, som en sejlende, der akkurat har strejfet en ukendt kyst, eller som en »Reporter «, der har set "the awful doors / Before the seal«. I »Behind me - dips Eternity" er den talende selve grænsen. Den poetiske stemme er en 'midterterm', der som en kile er drevet ind imellem 'evigheden' og 'udødeligheden':

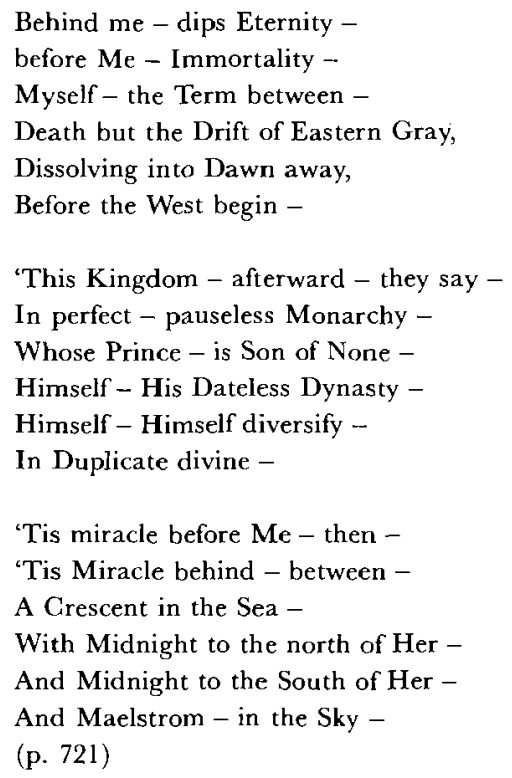

Grænsen i »ust lost ... skiller det dennesidige fra det hinsidige. Digtet opstiller en (simpel) modsætning mellem 'verden' og 'evig- 
hed', mellem en væren-i-tid og en væren løftet ud af tiden - en modsætning der kun antydningsvis kompliceres af den næsten umærkelige spejlvending, der finder sted mellem forste og anden strofe, idet 'land' og 'vand' så at sige bytter plads: billedet af jeg'et, stående ved bredden mens evighedens tidevand trækker sig tilbage, bliver til billedet af jeg'et, der som en sejlende når evighedens fremmede kyst. Geografien $\mathrm{i} »$ Behind me ...« er anderledes og merc kompleks: Evighed, udødelighed og "the term between «; væren udspændt mellem to identiske intetheder, nemlig den, der går forud, og den, der følger efter, eller den, der ligger bagved, og den, der ligger foran. Tidløsheden fra »Just lost ...« går igen her og kobles med en naiv, kristen forestilling om evigheden - en evighed der imidlertid hånligt-ironisk reduceres til ren negativitet. Det er karakteristisk, at digtets mange stedsangivelser (foran, bagved, nord, syd, øst og vest) kun har mening $\mathrm{i}$ forhold til det talende jeg, der fremstår som eneste kvalitet, eneste 'andethed' i et ellers perfekt og ubrudt negativt fravær. Som Sharon Cameron skriver: "'Eternity' og 'Immortality' synes at være spejle, der hænger overfor hinanden ¿. $^{14}$ Evighed og udødelighed er to spejle, der, uden den talendes tilstedeværelse, måtte reflektere hinandens tomhed. Uden midtertermens disruptive andethed ville »before" og »behind " flyde sammen til den forskelsløse enhed, der er absolut "fravær af mening “.

Det landskab, Dickinsons poetiske jeg bevæger sig i, omskabes og redefinercs af selve bevægelsen. Nedenstående digt er endnu et bidrag til dette univers' komplekse og mangetydige topografi:

\footnotetext{
Our journey had advanced -

Our feet were almost come

To that odd Fork in Being's Road -

Eternity - by Term -

Our pace took sudden awe -

Our feet - reluctant - led -

Before - were Cities - but Between -

The Forest of the Dead -

Retreat - was out of Hope -

Behind - a Sealed Route -

Eternity's White Flag - Before -

And God - at every Gate -

(P. 615)
}

Første strofe bringer digtets kollektive subjekt frem til det punkt, hvorfra jeg'et i »Just lost ... « blev drevet tilbage: korsvejen, tærsklen 
mellem liv og »eternity«. Men den dualisme, som korsvejen signalerer, bliver $\mathrm{i}$ anden strofe til en treleddet »before / between / behind»-struktur, lig og dog radikalt forskellig fra strukturen $\mathrm{i} \gg \mathrm{Be}$ hind me ..«. Det hinsides spaltes i »Eternity«, der ligger forud og forbliver en gåde, og døden, »the Forest of the Dead«, der nu fremstår som en mellemgrund, et ingenmandsland. Grænsen mellem liv og evighed har fået rumlig udstrækning. Med erkendelsen af forskellen mellem død og evighed er en grænse allerede overskredet: de tøvende, modvillige skridt har umærkeligt bragt subjektet ind i dødens midterzone, hvorfra der ikke er nogen vej tilbage. Vi er ikke længere »Before the Seal« (P. 160), men »Behind «.

Vi kan læse ovenstående digte som variationer over det Dickinsonske grænse-tema eller som faser i et ikke-lineært forløb: bevægelsen frem mod og - antydningsvis - henover uoverstigelige barrierer. Tilsammen demonstrerer disse digte, at Dickinsons poesi ikke blot afspejler en simpel dødslængsel eller en religiøst farvet higen efter 'det evige liv'. Hvad Dickinson søger er det umulige: Hun vil se $\gg$ the things ... / By Ear unheard, / Unscrutinized by Eye - « (P. 160), se det, der netop er uhørt og uset, fordi det er der, hvor al sansning hører op; hun vil erfare og bære vidnesbyrd om den »eternity«, der både er intethed og tilintetgørelse. Såvel Wordsworths som Dickinsons projekt er fra starten mærket af paradokser. Men hvor paradokset i The Prelude, ihvertfald som Wordsworth selv ser det, er at skulle give sprogligt udtryk for det, der ligger hinsides eller udenfor sprogets rækkevidde, så er Dickinsons paradoks forsøget på at begribe og fastholde bevidsthedens endelige og uigenkaldelige sammenbrud. Hun søger i eller gennem sproget netop den erfaring, der reelt er prækluderet: erfaringen om sin egen død.

Hos Wordsworth fremkalder forsøget på at »retrace / My life ... and measure back / The way I travell'd « (2:2-4, verbets form modificeret, LM) refleksioner over tiden og forholdet mellem subjektivitet og tidslighed. Tidsforholdet spiller ligeledes en afgørende rolle hos Dickinson. Også hendes 'rejse' er (omend på en anden vis end hos Wordsworth) en rejse i og gennem tiden, og det er gennem en remodellering af tidsoplevelsen, at hun poetisk søger at iscenesætte den erfaring, hun ønsker:

Because I could not stop for Death -

He kindly stopped for me -

The Carriage held but just Ourselves -

And Immortality. 


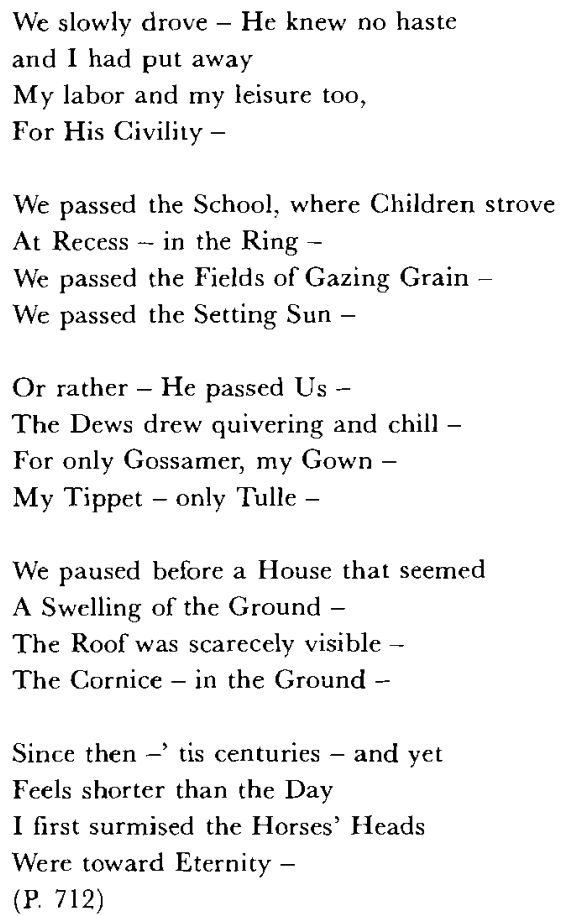

I 》Just lost, when I was saved « fremstilles modsætningen mellem det dennesidige og det hinsidige som modsætningen mellem væren-itid og væren udenfor tiden, og i »Behind me - dips Eternity - « associeres evighed og udødelighed med en negativ- "pauseless, dateless«-tidlighed. På tilsvarende vis forbinder »Because I could not stop for Death « passagen ud af verdenen med en reorganisering af tidsoplevelsen: 'overgangen' tematiseres som en seriel udskiftning af tidsrytmer eller som en destabilisering af forholdet mellem progression og regression og mellem bevægelse og stasis. Men det er i kraft af selve udsigelsens tidslighed snarere end af den tematiserede tid at dette digt $\mathrm{i}$ højere grad end de foregående kommer til at betegne en egentlig overskridelse.

Som en galant herre stopper døden for jeg'et, og idet hun stiger ind i vognen, træder hun samtidig ud af hverdagslivets tidsregning. Jeg'et lægger livets hektiske jag bag sig og hun bliver eet med vognens slow motion, der imidlertid, paradoksalt nok, samtidig har karakter af ekstrem fart, for som det hedder: "We passed the School, were Children strove / At recess - in the Ring«. Den langsomme køretur fremad, udad livet, er tilsyneladende på samme tid en hastig regressiv bevægelse, en bevægelse tilbage gennem livets stadier. Men bevæ- 
gelsens măl er stasis. I fjerde strofe, der betegner et vendepunkt i digtet, overhales vognen af tiden. "We passed the Setting Sun - / / Or rather - He passed Us«.

Bevægelse og tid forekommer nu at tilhøre en anden dimension; ekvipagen er løftet ud af både hverdagslivets målrettede tid og naturens cykliske tid. En grænse er krydset, og den kulde, som jeg'et pludselig registrerer, synes allerede at være en rigor mortis.

Vognen har nået sit bestemmelsessted, men digtet er endnu ikke ved vejs ende. Ekvipagens rolige bevægelse har ikke forberedt os på det skift, der nu finder sted: synsvinkelskiftet, der samtidig er et skift fra datidsform til nutidsform. I femte strofe betragter jeg'et graven udefra; den er kun lige akkurat antydet som $"$ A swelling of the Ground «. I sidste strofe er graven for længst passeret. Indtil da har vi haft del i vognens bevægelse: læsningen har haft samme retning som "the Horses' Heads«. Nu antager datidsformen retroaktivt en ny betydning: vi erfarer med eet, at hele forløbet erindres. Vognens bevægelse ud af tiden er i sig selv indlejret $i$ en tidsstruktur: Beretningen om køreturen frem mod »Eternity« er en retrospektiv beretning, fortalt fra et ubestemt og ubestemmeligt sted; et sted hinsides graven?

"Because I could not stop for Death « både fuldbyrder og omgår den endelige grænseerfaring. Det er, som om det vigtigste kun er til stede som et tomrum i teksten, et tomrum der materielt markeres af den tomme linie mellem femte og sjette strofe. Femte strofe har bragt os frem til det punkt, hvor den afgørende barriere - graven - skal forceres; i sjette strofe er dette punkt fortid, og gennem påpegningen af erindringsformen rettes opmærksomheden atter mod selve køreturen "toward Eternity«. Et skæringspunkt udpeges, men selve overgangen forbliver unævnelig; den er det fravær, hele digtet kredser om. "I felt a Funeral, in my Brain « kan siges at udfylde dette tomrum men formår kun at gøre det, fordi døden her er en metafor:

I felt a Funeral, in my Brain,

And Mourners to and fro

Kept treading - treading - till it seemed

That Sense was breaking through -

And when they all were seated,

A Service, like a Drum -

Kept beating - beating - till I thought

My Mind was going numb - 
And then I heard them lift a Box

And creak across my Soul

With those some Boots of Lead, again,

Then Space - began to toll,

As all the Heavens were a Bell,

And Being, but an Ear,

And I, and Silence, some strange Race

Wrecked, solitary, here -

And then a Plank in Reason, broke,

And I dropped down, and down -

And hit a World, at every plunge,

And Finished knowing - then -

(P. 280)

Ved digtets begyndelse er den talende allerede død. Men døden er en metafor for en sjælelig tilstand, for scenen er »my Brain«: et indre rum befolket af et 'jeg' lagt i en kiste og 'de andre', de sørgende efterladte, der må læses som materialiseringen af et udspaltet aspekt af selvet. Hele digtet er som et kinesisk æskesystem: inden i hjernekisten en anden kiste; inden i jeg'et andre jeg'er. Både strukturelt og indholdsmæssigt ligger digtet tæt op ad »I felt a Cleaving in my Mind «, som er citeret ovenfor: I begge skildres en sjælelig opspaltning eller fragmentering, som flere kritikere har betegnet som en (grænse-)psykotisk oplevelse. ${ }^{15}$ Det billede, der tegnes, kan give associationer til Wordsworths fremstiling af sine »two consciousnesses «: spaltningen mellem jeg'et ved graven og jeg'et under mulde - blot med den vasentlige og makabre forskel at synsvinklen her konsekvent ligger hos jeg'et i kisten. Graven betragtes så at sige 'indenfra' eller 'nedenfra' (en vinkel der understreges af, at jeg'et er afskåret fra at se, hvad der foregår 'udenfor', mens høre- og følesansen til gengæld er pinefuldt skærpet). Denne forskydning i forhold til Wordsworths forestilling om det spaltede selv tvinger os til at antage endnu en jegfordobling: Det 'jeg', der siger »I felt " kan hverken være det 'jeg', der følte, eller det 'jeg', der blev 'begravet': Denne fordobling synes at være selve udsagnets mulighedsbetingelse. Bevidsthedstabet (og sprogets sønderbrydning) kan kun fortælles af et jeg, der har lagt denne oplevelse bag sig.

»Et digts strejfen hen over umulige ydergrænser får uundgåeligt andre grænser til at bryde sammen, nemlig de der har rejst sig som mure mellem figuren og det, der udtrykkes figurativt, eller mellem bogstavelige figurative betydninger«, skriver Cameron (op.cit. p. 92). Måske kan vi vende lidt rundt på dette udsagn: Det er grænsen 
mellem »figur« (død, begravelse) og "det der udtrykkes figurativt» (psykotisk oplevelse), som fastholder »I felt ...« indenfor det muliges grænser. Eller anderledes udtrykt: Det er i sammenbruddet af barrieren mellem det figurative og det bogstavelige at overskridelsen fuldbyrdes. Et sådant sammenbrud er $\gg I$ heard a Fly buzz - when I died «, der kan læses som kulminationen af den Dickinsonske grænseerfaring. »I heard « - »I felt«: digtet associerer klart til det foregående. Faktisk forløber de to digte helt parallelt: i begge finder vi således det mærkværdige tidsinterval (en form for 'forsinkelse') mellem 'død' og 'bevidsthedstab'. Men der er en markant forskel. Døden er hverken metaforiseret (som i "Because I could not stop for Death «) eller metafor; den er sig selv. En »umulig grænse« forceres, idet Dickinson fastholder det bogstavelige i et udsagn, der kun burde læses figurativt.

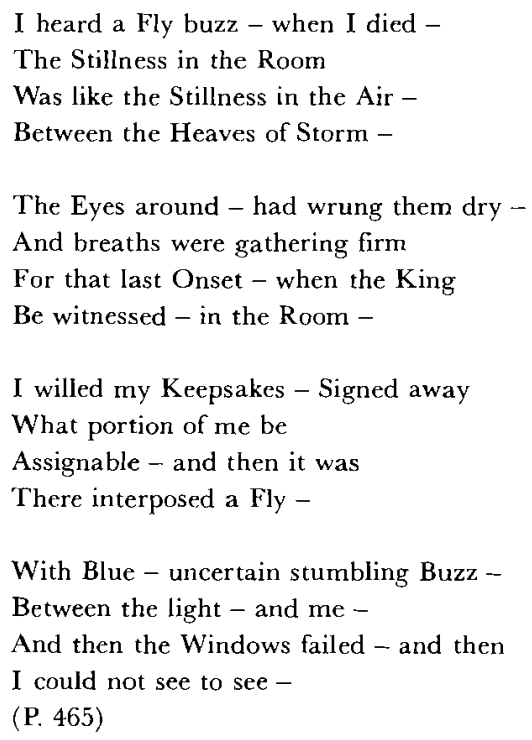

„I felt a Funeral ...«s beretning om jeg-opløsning, fortalt af et jeg, der har afgrænset sig fra den psykotiske oplevelse, er det tætteste, Dickinson kan komme på en logisk og sproglig plausibel iscenesættelse af den døds-erfaring, som jeg'et både frygter og higer efter. "I heard a Fly buzz ... « går et skridt videre. Digtets bevægelse er dødsprocessen, bevægelsen ned mod sansningens og bevidsthedens ophør. 'Det hinsides' gøres ikke til en 'anden verden', men fastholdes som intethed. Efter den sidste tankestreg er kun stumhed mulig; og dog er dette 'stumme sted' netop det sted, hvorfra der tales. Bevidstheden 
overlever sig selv, men kun for at erfare og bære vidnesbyrd om sin egen tilintetgørelse.

Poe udgav i 1845 fortællingen »The Facts in the Case of M. Valdemar«, der er beretningen om M. Valdemar, som i selve dødsøjeblikket mesmeriseres og derved hensættes i en trancelignende tilstand - en tilstand der på een gang er død og dødens udsættelse. Under trancen udspørger hypnotisøren (novellens jeg-fortæller) den mesmeriserede: "I had asked him, it will be remembered, if he still slept. He know said: 'Yes; - no; - I have been sleeping - and now - now - I am dead. $"{ }^{16}$ I artiklen »Textual Analysis of Poe's 'Valdemar'" diskuterer Roland Barthes dette udsagn, og hans kommentarer, som jeg her afslutningsvis skal gengive uddrag af, er af højeste relevans for den Dickinsonske grænseoverskridelse:

\begin{abstract}
Den forestilling, at den døde mand kan fortsætte med at handle, er banal ... Men her er den døde mands handling en ren sproglig handling, og som kronen på værket har hans sprog intet formål ... selve ubrugeligheden af det, der tilbydes, er en del af skandalen: det drejer sig om at bekræfte en essens, der ikke er på sin rette plads ... En anden skandale i udsigelsen er metaforens forvandling til det bogstavelige ... Når det drejer sig om lige præcis denne metafor, er forvandlingen af det metaforiske til det bogstavelige umulig: udsagnet 'jeg er død' er helt bogstaveligt prækluderet ... Det drejer sig altså om en sprogets skandale ... I den ideelle sum af mulige ytringer i sproget er koblingen mellem første person (jeg) og egenskaben 'død' netop den, der er radikalt umulig: det er denne tomme plads, denne sprogets blinde plet, som fortællingen, meget nøjagtigt, kornmer til at bebo. ${ }^{17}$
\end{abstract}

Det Dickinsonske jeg, der i erindringens datidsform siger »when I died «, har del i den »skandale«, Barthes taler om: en skandale der både er en logisk skandale - idet digtet, som Cameron påpeger, fastholder to indbyrdes uforenelige forestilliner, nemlig at »døden er livets afslutning « og »sansningen er livets afslutning “ (op.cit. p. 121) - og en sproglig skandale, nemlig det bogstaveliges umulige tilbagevenden $i$ et udsagn, hvor det bogstavelige er prækluderet. At udfylde den 'blinde plet' i sproget er Dickinsons poetiske projekt.

1. William Wordsworth, The Prelude. The Prelude er Wordsworth's poetiske selvbiografi, en rejse tilbage i tiden for at efterspore »the Growth of a Poet's Mind «. I det folgende citeres fra 1805-teksten: The Prelude, ed. Ernest de Selincourt (Oxford: Oxford University Press, 1970).

2. Jean Starobinski, »The Inside and the Outside«, Hudson Review 28, no. 3 (Autumn 1975), p. 335. Ligesom de passager, der citeres nedenfor, er denne passage oversat af mig, LM.

3. Passagen (The Prelude 5:389-422) citeres nedenfor i sin helhed.

4. Ved sin død i 1886 efterlod Emily Dickinson sig 1775 digte, hvoraf kun ganske få tidligere havde været offentliggjort. I det folgende citeres fra The Complete Poems of Emily Dickinson, ed. 
Thomas H. Johnson (Boston: Little, Brown and Company). Tallene i parentes henviser til Johnsons autoriserede nummerering.

5. Joanne Feit Diehl, Dickinson and the Romantic Imagination (Princeton N.J.: Princeton University Press, 1981), p. 4.

6. Termerne 'analepsis' og 'prolepsis' er lånt fra Gérard Genette, Narrative Discourse (Itacha N.Y.: Cornell University Press, 1980). Termen 'prolepsis' er hentet fra den klassiske retorik, hvor den betegner en sproglig manøvre, hvorigennem en senere begivenhed forudgribes. 'Analepsis', derimod, er Genettes egen neologisme. Analepsis betegner det modsatte af prolepsis, nemlig senhver efterlods påkaldelse af en begivenhed, der fandt sted forud for det punkt i historien, hvor vi befinder os på et givet tidspunkt« (p. 40). Jeg bruger 'analepsis' og 'prolepsis' på en lidt anden måde end Genette, nemlig til at betegne henholdsvis Wordsworths tilbageblik fra det nutidspunkt, der udgør 'fortælle-planet' i The Prelude og Dickinsons forudskikkelse af den ded, der venter forude.

7. Frances Ferguson, Wordsworth: Language as Counter-Spirit (New Haven: Yale University Press, 1977) p. 137.

8. I en tidligere version af $11.389-413$ benyttes fra og med 1.400 " $\ll$ som gennemgående personligt pronomin.

9. Charles Sherry Wordsworth's Poetry of the Imagination (New York, 1980) p. 95.

10. Se Ferguson, f.eks. p. 245.

11. The Prose Works of William Wordsworth, ed. Owen and Smyser (Oxford: Oxford University Press, 1974) vol. II, p. 63.

12. Se f.eks. pasagerne om 'Araberdrømmen' (5:49-139) og 'den druknede mand' (5:450-81).

13. Især de to sidste linier forekommer at være et ekko af Wordsworths beretning om den druknede mand: The succeding day, / (Those unclaimed garments telling a plain Tale) / Went there a Company, and, in their Boat / Sounded with grappling irons, and long poles. etc. (5:466-69)

14. Sharon Cameron, Lyric Time. Dickinson and the Limits of Genre (Baltimore \& London: The Johns Hopkins University Press, 1979) p. 75.

15. Se f.eks. John Cody, After Great Pain: The Inner Life of Emily Dickinson (Cambridge Mass., 1971).

16. The Complete Workds of Edgar Allan Poe (New York: AMS Press, 1965) Vol VI, p. 163.

17. Roland Barthes, "Textual Analysis of Poe's 'Valdemar'«, in Untying the Text, ed. Robert Young (Boston, 1981), p. 153-54. 